\title{
The Role of Ascorbic Acid in the Mosaic of Coronary Heart Disease: Lipid Metabolism and Antioxidant Functions
}

\author{
Cheryl L. Alwan, ${ }^{1}$ Andrew J. Brown, ${ }^{2}$ Vicki A. Cooper, ${ }^{1}$ and Samir Samman ${ }^{1, *}$ \\ ${ }^{1}$ Human Nutrition Unit, Department of Biochemistry, \\ University of Sydney, NSW 2006, Australia \\ ${ }^{2}$ Cell Biology Unit, Heart Research Unit, Missenden Road, \\ Camperdown, N.S.W., 2050, Australia
}

\begin{abstract}
Summary Ascorbic acid (AA) is purported to have a preventative role in coronary heart disease (CHD) incidence. Studies in animal models support an interaction of AA in lipid metabolism, while results from epidemiological and supplementation trials conducted in humans are inconsistent. However, AA may mediate its protective action against CHD via its function as an antioxidant, inhibiting lipid peroxidation and regenerating $\alpha$-tocopherol. Although AA can exert potentially beneficial effects, excessive AA administration can lead to damaging effects via interactions with transition metals, such as iron and copper.
\end{abstract}

Key Words: ascorbic acid, coronary heart disease, lipid metabolism, antioxidants, copper, iron

Epidemiological evidence is suggestive of a protective role for ascorbic acid (AA) against coronary heart disease (CHD). While a high dietary AA intake has been linked with decreased incidence of coronary mortality [1, 2], epidemiological evidence has associated low plasma AA levels with increased risk of CHD [35]. AA has a demonstrated protective effect in vitro against oxidative modification of lipoproteins [6], which are implicated in atherogenesis [7]. AA may also enhance the antioxidant protection provided by $\alpha$-tocopherol, the major lipidsoluble chain-breaking antioxidant present in low density lipoprotein (LDL). This is mediated via AA's regeneration of $\alpha$-tocopherol from its oxidation product, the tocopheroxyl radical [8]. The purpose of this review is to examine the suggested protective effects of AA against CHD. It will primarily focus on AA's function in lipid metabolism and its antioxidant properties. The potential adverse effects of excessive AA consumption will also be discussed briefly.

\footnotetext{
*To whom correspondence should be addressed.
} 


\section{EFFECT OF AA ON LIPID METABOLISM}

Studies in animals. The role of AA in lipid metabolism has been studied extensively in guinea pigs as, like humans, they are incapable of synthesizing AA. Long term hypovitaminosis $\mathrm{C}$ resulted in the accumulation of cholesterol in blood serum and/or a number of tissues, including the liver and the thoracic aorta [9], possibly due to a decreased rate of cholesterol catabolism $[10,11]$. In genetically modified rats unable to synthesize AA, AA deficiency resulted in elevated serum and liver concentrations of cholesterol regardless of whether rats were fed a normal or cholesterol-containing diet [12]. In other studies involving transgenic rats, AA deficiency caused serum total cholesterol (TC) and low density lipoprotein-cholesterol (LDL-C) levels to be elevated and high density lipoprotein-cholesterol (HDL-C) levels to be lowered [13, 14]. In contrast, a decrease in the cholesterol level of the serum, liver and aorta was observed in weanling rats fed a large dose of AA for one month [15]. Similarly, in guinea pigs receiving an atherogenic diet, high doses of AA resulted in reductions in liver and aorta cholesterol levels and serum triglyceride (TG) levels [16].

Epidemiological studies. The relationship between AA and HDL-C is of considerable interest as HDL-C is inversely associated with CHD [17]. Several [18-26] but not all [27] studies have reported a positive correlation between plasma AA and HDL-C concentrations (Table 1). This has been demonstrated in groups of varying ages, genders and cultural backgrounds. Similarly, while most studies have reported a positive correlation between dietary AA intake and plasma HDL-C levels [28, 29], another found no association between these two parameters [30]. The balance of the epidemiological studies suggests an inverse association between AA and HDL-C (Table 1).

Inverse associations have been reported between plasma AA and plasma TC $[19,22,25,31,32]$, LDL-C [25] and TG [22, 25, 26, 31] levels (Table 1). In contrast, a positive correlation was shown to exist between serum TC and both plasma and leucocyte AA levels in Kenyan tribespeople [33]. Interestingly, Hallfrisch and colleagues [23] found a negative association between plasma AA and plasma TC, LDL-C and TGs in men, but the opposite association in women. However, as for the relationship with AA and HDL-C, a number of investigators have not demonstrated a significant association between plasma or leucocyte AA and TC, LDL-C, and TG concentrations (Table 1). Consequently, the epidemiological studies demonstrate that the relationships between AA and TC, LDL-C and TGs are inconsistent.

Supplementation studies. Supplementation trials have been conducted to test the epidemiological association between plasma AA and plasma lipids (Table 2). The results of some trials demonstrated a beneficial influence [35-38], while in some cases, AA administration has been shown to have no effect on different plasma lipids [39-52], despite the wide range of doses $(0.15-6 \mathrm{~g} / \mathrm{day})$ administered 
Table 1. Epidemiological studies investigating the relationship between AA and plasma lipids.

\begin{tabular}{|c|c|c|}
\hline Subjects & Results & $\begin{array}{l}\text { Comments } \\
\text { [reference] }\end{array}$ \\
\hline $254 \mathrm{~F}$ (Wales) & No effect. & $-[34]$ \\
\hline $23 \mathrm{M}, 11 \mathrm{~F}$ (Kenya) & $\begin{array}{l}\text { Positive correlation between serum cholesterol } \\
\text { and both PAA and LAA. }\end{array}$ & AA levels low [33]. \\
\hline $\begin{array}{l}12 \mathrm{M}, 11 \mathrm{~F} \text {; healthy } \\
\text { elderly, } 72-86 \mathrm{y}\end{array}$ & $\begin{array}{l}\text { Positive correlation between PAA and } \\
\text { WBC-AA and plasma HDL-C in M. }\end{array}$ & $\begin{array}{l}\text { Correlation based on } \\
\text { average of three- } \\
\text { monthly values taken } \\
\text { over } 18 \text { months }[18] .\end{array}$ \\
\hline $\begin{array}{l}300 \mathrm{M}, 300 \mathrm{~F} ; \text { blood- } \\
\text { donors, } 25-55 \mathrm{y}\end{array}$ & $\begin{array}{l}\text { Negative linear correlation between LAA } \\
\text { levels and levels in } \mathrm{M} \text { and } \mathrm{F} \text { for TC and TG. }\end{array}$ & $-[31]$ \\
\hline $97 \mathrm{M} ; 30-69 \mathrm{y}$ & $\begin{array}{l}\text { PAA negatively associated with TC and } \\
\text { weakly but positively associated with HDL-C. } \\
\text { No association between PAA and TG. }\end{array}$ & $\begin{array}{l}\text { Random sample; } \\
\text { controlled for age; } \\
\text { known alteration of } \\
\text { AA metabolism in } \\
\text { the elderly [19]. }\end{array}$ \\
\hline $100 \mathrm{M}+\mathrm{F} ; 70-84 \mathrm{y}$ & $\begin{array}{l}\text { Significant negative correlation between PAA } \\
\text { and TC in M. No correlation between PAA } \\
\text { and TGs. }\end{array}$ & $\begin{array}{l}\text { Seasonal variation in } \\
\text { PAA evident; altered } \\
\text { AA metabolism in } \\
\text { the elderly [32]. }\end{array}$ \\
\hline $13 \mathrm{M}, 16 \mathrm{~F} ; 20-53 \mathrm{y}$ & $\begin{array}{l}\text { Positive correlation between HDL-C and } \\
\text { AA intake in F. }\end{array}$ & $\begin{array}{l}\text { Serum AA levels not } \\
\text { measured [28]. }\end{array}$ \\
\hline $\begin{array}{l}\text { 1,166 M (Eastern } \\
\text { Finnish); } 54 \mathrm{y}\end{array}$ & $\begin{array}{l}\text { PAA not associated with HDL-C or } \\
\text { LDL-C. }\end{array}$ & $-[27]$ \\
\hline 146 F, 92 M; Chinese- & Partial correlation between PAA and plasma & Altered AA \\
\hline Americans, $\geqq 60 \mathrm{y}$ & HDL-C in predominantly non-smoking $\mathrm{F}$. & $\begin{array}{l}\text { metabolism in the } \\
\text { elderly [20]. }\end{array}$ \\
\hline $\begin{array}{l}148 \mathrm{M}, 93 \mathrm{~F} \text {; elderly } \\
\text { Chinese-Americans }\end{array}$ & $\begin{array}{l}\text { Positive correlation between PAA and } \\
\text { HDL-C. }\end{array}$ & Abstract only [21]. \\
\hline $\begin{array}{l}79 \mathrm{M}, 96 \mathrm{~F} \\
\text { (Japan); } \geqq 60 \mathrm{y}\end{array}$ & $\begin{array}{l}\text { Positive correlation between HDL-C and AA } \\
\text { found in M and in F. PAA is negatively } \\
\text { correlated with TG. PAA is negatively } \\
\text { correlated with plasma TC in F. }\end{array}$ & $\begin{array}{l}\text { Adjusted for several } \\
\text { confounding } \\
\text { variables; altered AA } \\
\text { metabolism in the } \\
\text { elderly [22]. }\end{array}$ \\
\hline $\begin{array}{l}17 \mathrm{M}, 17 \mathrm{~F} \text {; body- } \\
\text { builders }\end{array}$ & $\begin{array}{l}\text { AA intake was positively associated with } \\
\text { HDL-C for M. }\end{array}$ & $\begin{array}{l}\text { PAA not measured } \\
{[29] .}\end{array}$ \\
\hline 2,379 girls; $9-10 y$ & $\begin{array}{l}\text { Negative association between dietary AA } \\
\text { intake and serum TC in a subgroup with } \\
\text { TC levels } \geqq 200 \mathrm{mg} / \mathrm{dl} \text {. Dietary AA intake } \\
\text { associated inversely with LDL-C. }\end{array}$ & $\begin{array}{l}\text { Diet controlled; PAA } \\
\text { not measured [30]. }\end{array}$ \\
\hline 316 F, $511 \mathrm{M} ; 19-95$ y & $\begin{array}{l}\text { Positive correlation between PAA with: } \\
\text { HDL-C in M; TC, LDL-C, and TGs in F. } \\
\text { A negative association between PAA and } \\
\text { plasma TC, LDL-C and TGs in M. }\end{array}$ & $\begin{array}{l}\text { Adjusted for several } \\
\text { confounding factors; } \\
\text { correlations given for } \\
\text { a subsample of the } \\
\text { population [23]. }\end{array}$ \\
\hline $256 \mathrm{M}, 221 \mathrm{~F} ; 20-65$ y & $\begin{array}{l}\text { Positive association between AA and HDL-C, } \\
\text { and inverse association between AA and TC, } \\
\text { LDL-C and TGs in M. AA positively } \\
\text { associated with HDL-C in F. }\end{array}$ & $\begin{array}{l}\text { Adjusted for several } \\
\text { confounding factors } \\
{[25] .}\end{array}$ \\
\hline
\end{tabular}

Vol. 26, No. 2, 1999 


\begin{tabular}{llc}
\hline \multicolumn{1}{c}{ Subjects } & \multicolumn{1}{c}{ Results } & $\begin{array}{c}\text { Comments } \\
\text { [reference] }\end{array}$ \\
\hline $835 \mathrm{M}, 1,025 \mathrm{~F} ;$ & $\begin{array}{l}\text { Serum AA not correlated with serum TC or } \\
\text { LDL-C. Serum AA positively correlated with } \\
\text { H5-75 y }\end{array}$ & $\begin{array}{l}\text { Non-fasting samples; } \\
\text { diet not included as a } \\
\end{array}$ \\
& F. & \\
\hline
\end{tabular}

$\mathrm{AA}=$ ascorbic acid; $\mathrm{F}=$ female; HDL-C $=$ high density lipoprotein-cholesterol; $\mathrm{LAA}=$ leucocyte ascorbic acid; LDL-C =low density lipoprotein-cholesterol; $\mathrm{M}=$ male; PAA = plasma ascorbic acid; $\mathrm{TC}=$ total cholesterol; $\mathrm{TG}=$ triglycerides; $\mathrm{WBC}-\mathrm{AA}=$ white blood cell ascorbic acid.

(Table 2). Interestingly, an exception to the above observations was a study conducted by Spittle [53], who showed that while AA supplementation of $1 \mathrm{~g} / \mathrm{day}$ over 6 weeks resulted in a significant increase in serum TC in atherosclerotic patients, no significant effect was observed in patients without atherosclerosis.

While there is a plethora of evidence from studies in animals to substantiate the postulated influence of AA on lipid metabolism, the evidence derived from studies in humans has been inconsistent. Consequently, studies in humans have failed to demonstrate a link of AA with CHD. Overall, the quality of both epidemiological and supplementation studies has been variable. The majority of trials reviewed have suffered from limitations. Some of these include the lack of a control group or randomization, low statistical power, poor dietary control, failure to blind, no evidence of compliance, a heterogeneous population with respect to pathological conditions and AA status, and the use of elderly subjects who have a recognized age-related alteration in the metabolism of AA. Further controlled human studies of appropriate design are warranted to elucidate the relationship between AA and CHD.

Postulated mechanisms for the effect of AA on lipid metabolism. AA may influence lipid metabolism in different ways. In guinea pigs, the catabolism of cholesterol to bile acids is hindered by low AA levels [11, 54-57]. A significant linear correlation has been observed between the rate of cholesterol conversion to bile acids and the AA concentration in the liver of guinea pigs [11,55]. AA-deficient guinea pigs have reduced bile acid synthesis due to a reduction in the activity of cholesterol $7 \alpha$-hydroxylase, the rate-limiting enzyme in bile acid synthesis $[9$, 57-60]. Bjorkhem and Kallner [58] found that AA affected cytochrome P-450 whose main function is to activate the oxygen used by $7 \alpha$-hydroxylase during the hydroxylation of cholesterol [36]. AA may mediate a reduction in plasma LDL-C concentrations, as AA supplementation has been shown to increase the number of LDL receptors in cultured smooth muscle cells [61]. The manner in which AA influences HDL-C metabolism has not been ascertained. It appears that the lipoprotein lipase (LPL) activity is elevated by AA, and that this enzyme is subsequently involved in the regulation of HDL metabolism [62]. It has been 
Table 2. Supplementation trials investigating the relationship between AA and plasma lipids.

\begin{tabular}{|c|c|c|c|}
\hline Subjects & $\begin{array}{l}\text { Interven- } \\
\text { tion period } \\
\text { (AA dose) }\end{array}$ & Results & Comments [reference] \\
\hline $\begin{array}{l}8 \mathrm{M}, 6 \mathrm{~F} \\
\text { hyperchole- } \\
\text { sterolemia with } \\
\text { defined arterio- } \\
\text { sclerosis, 9-56 y }\end{array}$ & $\begin{array}{l}5-16 \\
\text { weeks, } \\
1-6 \mathrm{~g} / \mathrm{d}\end{array}$ & No effect. & $\begin{array}{l}\text { Serum AA not measured; not } \\
\text { diet-controlled; no control } \\
\text { group or randomization [39]. }\end{array}$ \\
\hline $\begin{array}{l}58 \text { volunteers; } 33 \\
\text { with history of } \\
\text { atherosclerosis }\end{array}$ & $\begin{array}{l}6 \text { weeks, } \\
1 \mathrm{~g} / \mathrm{d}\end{array}$ & $\begin{array}{l}\text { Significant increase in serum } \\
\text { TC in patients with athero- } \\
\text { sclerosis; no effect in other } \\
\text { groups. }\end{array}$ & $\begin{array}{l}\text { No placebo control; serum AA } \\
\text { not measured; not } \\
\text { diet-controlled [53]. }\end{array}$ \\
\hline $\begin{array}{l}18 \mathrm{M}, 16 \mathrm{~F} \\
\text { healthy subjects, } \\
19-40 \mathrm{y}\end{array}$ & $\begin{array}{l}3 \text { months, } \\
1 \mathrm{~g} / \mathrm{d}\end{array}$ & No effect. & $\begin{array}{l}\text { Non-fasting blood samples; } \\
\text { serum AA not measured; } \\
\text { randomized, not blinded and } \\
\text { no placebo control }[40] \text {. }\end{array}$ \\
\hline $\begin{array}{l}14 \mathrm{~F}, 108 \mathrm{M} \\
18-25 \text { y }\end{array}$ & $\begin{array}{l}4 \text { months, } \\
1 \mathrm{~g} / \mathrm{d}\end{array}$ & No effect. & $\begin{array}{l}\text { Randomized, placebo- } \\
\text { controlled, single-blinded } \\
\text { study; not diet-controlled [41]. }\end{array}$ \\
\hline $\begin{array}{l}6 \mathrm{M}, 3 \mathrm{~F} \text {; with } \\
\text { hyperlipidemia, } \\
26-57 \text { y }\end{array}$ & $\begin{array}{l}8 \text { weeks, } \\
4 \mathrm{~g} / \mathrm{d}\end{array}$ & $\begin{array}{l}\text { No effect of AA supplementa- } \\
\text { tion on plasma TC and TG } \\
\text { levels or their distribution in } \\
\text { lipoproteins. }\end{array}$ & $\begin{array}{l}\text { Diet-controlled; no control } \\
\text { group or randomization [42]. }\end{array}$ \\
\hline $\begin{array}{l}\text { Hyperlipidemic } \\
\text { subjects with low } \\
\text { PAA levels at } \\
\text { baseline }\end{array}$ & $\begin{array}{l}12 \\
\text { months, } \\
1 \mathrm{~g} / \mathrm{d}\end{array}$ & $\begin{array}{l}\text { Decrease in plasma TC and TG } \\
\text { levels. }\end{array}$ & $\begin{array}{l}\text { No control group; AA-deficient } \\
\text { patients }[35] \text {. }\end{array}$ \\
\hline $40 \mathrm{M}$; with CAD & $\begin{array}{l}6 \text { months, } \\
0-2 \mathrm{~g} / \mathrm{d}\end{array}$ & $\begin{array}{l}\text { Supplementation with } 2 \mathrm{~g} \mathrm{AA} / \\
\mathrm{d} \text { caused the serum cholesterol } \\
\text { levels to decrease by } 12 \% \text {, but } \\
\text { did not change TG levels. }\end{array}$ & $\begin{array}{l}\text { Randomized, double-blinded, } \\
\text { placebo-controlled trial with } \\
\text { control group; all subjects had } \\
\text { low to normal AA levels at the } \\
\text { initiation of the study [43]. }\end{array}$ \\
\hline $9 \mathrm{M} ; 23-36$ y & $\begin{array}{l}6 \text { weeks, } \\
1 \mathrm{~g} / \mathrm{d}\end{array}$ & No effect. & $-[44]$ \\
\hline $13 \mathrm{~F} ; 21-28 \mathrm{y}$ & $\begin{array}{l}4 \text { weeks, } \\
1 \mathrm{~g} / \mathrm{d}\end{array}$ & No effect. & $-[45]$ \\
\hline $\begin{array}{l}40 \mathrm{M} \text {; healthy, } \\
\text { free-living, } \\
21-35 \mathrm{y}\end{array}$ & $\begin{array}{l}6 \text { weeks, } \\
2 \mathrm{~g} / \mathrm{d}\end{array}$ & $\begin{array}{l}\text { The subject with the lowest } \\
\text { baseline PAA and WBC-AA } \\
\text { levels had the sharpest decline } \\
\text { in TC and LDL-C coupled } \\
\text { with an elevation in HDL-C }\end{array}$ & $\begin{array}{l}\text { Diet-controlled; other } \\
\text { interventions apart from AA } \\
\text { supplementation also } \\
\text { examined; blinded, } \\
\text { placebo-controlled trial [46]. }\end{array}$ \\
\hline $\begin{array}{l}20 \mathrm{M} \text {; normo- } \\
\text { cholesterolemic } \\
20 \mathrm{M} \text {; hyper- } \\
\text { cholesterolemic, } \\
44-79 \text { y }\end{array}$ & $\begin{array}{l}3 \text { weeks, } \\
3 \mathrm{~g} / \mathrm{d}\end{array}$ & $\begin{array}{l}\text { Decreased plasma TC and TG } \\
\text { levels in all subjects. }\end{array}$ & PAA not measured $[36]$ \\
\hline $\begin{array}{l}8 \mathrm{M}, 1 \mathrm{~F} \text {; with } \\
\text { hypertriglycer- } \\
\text { idemia, } 41-65 \text { y }\end{array}$ & $\begin{array}{l}1 \text { month, } \\
2 \mathrm{~g} / \mathrm{d}\end{array}$ & No effect. & $\begin{array}{l}\text { AA levels and AA status not } \\
\text { determined [47]. }\end{array}$ \\
\hline
\end{tabular}

Vol. 26, No. 2, 1999 
Table 2 (Continued)

\begin{tabular}{|c|c|c|c|}
\hline Subjects & $\begin{array}{l}\text { Interven- } \\
\text { tion period } \\
\text { (AA dose) }\end{array}$ & Results & Comments [reference] \\
\hline $\begin{array}{l}3 \text { groups: } 14 \mathrm{M} \\
\text { and } 15 \mathrm{~F} ; 21-61 \text { y }\end{array}$ & $\begin{array}{l}0-12 \\
\text { months, } \\
0-2 \mathrm{~g} / \mathrm{d}\end{array}$ & $\begin{array}{l}\text { Fall in serum TC following } \\
\text { supplementation with } 1 \text { and } 2 \\
\text { g AA/d. }\end{array}$ & $\begin{array}{l}\text { Age-related delay in } \\
\text { cholesterol-lowering by AA } \\
\text { [37]. }\end{array}$ \\
\hline $130 \mathrm{M} ; 65-74$ y & $\begin{array}{l}6 \text { weeks, } \\
150 \mathrm{mg} / \mathrm{d}\end{array}$ & No effect. & $\begin{array}{l}\text { Initial AA levels low }(\leqq 0.23 \\
\mathrm{mg} / \mathrm{dl})[48]\end{array}$ \\
\hline $\begin{array}{l}27 \mathrm{~F} \text {; hospital } \\
\text { patients with low }\end{array}$ & $\begin{array}{l}6 \text { weeks } \\
\text { for each }\end{array}$ & No effect. & $\begin{array}{l}\text { Randomized, placebo-con- } \\
\text { trolled trial; known alteration }\end{array}$ \\
\hline PAA levels, & dose, 0.2 & & of $\mathrm{AA}$ metabolism in the \\
\hline 68-93 y & $\mathrm{g} / \mathrm{d} ; 2 \mathrm{~g} / \mathrm{d}$ & & $\begin{array}{l}\text { elderly and patients where AA- } \\
\text { deficient }(<6.0 \mathrm{mg} / \text { liter })[49] \text {. }\end{array}$ \\
\hline $\begin{array}{l}138 \text { M,F: healthy } \\
\text { adults, } 20-65 \text { y }\end{array}$ & $\begin{array}{l}8 \text { months, } \\
1 \mathrm{~g} / \mathrm{d}\end{array}$ & $\begin{array}{l}\text { AA supplementation } \\
\text { significantly increased HDL-C } \\
\text { among subjects with lower } \\
\text { baseline PAA levels. }\end{array}$ & $-[50]$ \\
\hline $10 \mathrm{~F}$; nonsmokers & $\begin{array}{l}4 \text { weeks, } \\
1 \mathrm{~g} / \mathrm{d}\end{array}$ & $\begin{array}{l}\text { AA supplementation resulted } \\
\text { in a significant decline in } \\
\text { plasma LDL-C levels. }\end{array}$ & Carry-over effect of AA [38]. \\
\hline $\begin{array}{l}59 \mathrm{M} ; \text { smokers, } \\
36-65 \text { y }\end{array}$ & $\begin{array}{l}2 \text { months, } \\
0.5 \mathrm{~g} / \mathrm{d}\end{array}$ & $\begin{array}{l}\text { LDL-C decreased significantly } \\
\text { in slow release AA group. }\end{array}$ & $\begin{array}{l}\text { Randomized, single-blinded, } \\
\text { placebo-controlled trial; not } \\
\text { diet-controlled [51]. }\end{array}$ \\
\hline $8 \mathrm{M}$; smokers & $\begin{array}{l}2 \text { weeks, } \\
1 \mathrm{~g} / \mathrm{d}\end{array}$ & $\begin{array}{l}\text { AA supplementation produced } \\
\text { no changes in plasma TC, TGs, } \\
\text { or the distribution of } \\
\text { cholesterol among the } \\
\text { lipoprotein fractions. }\end{array}$ & $\begin{array}{l}\text { Randomized, single-blinded, } \\
\text { placebo-controlled, crossover } \\
\text { trial; subjects served as their } \\
\text { own control; diet-controlled; } \\
\text { small number of subjects [52]. }\end{array}$ \\
\hline
\end{tabular}

$\mathrm{AA}=$ ascorbic acid; $\mathrm{F}=$ female; HDL-C $=$ high density lipoprotein-cholesterol; $\mathrm{LAA}=$ leucocyte ascorbic acid; LDL-C =low density lipoprotein-cholesterol; $\mathrm{M}=$ male; $\mathrm{PAA}=$ plasma ascorbic acid; $\mathrm{TC}=$ total cholesterol; $\mathrm{TG}=$ triglycerides; $\mathrm{WBC}-\mathrm{AA}=$ white blood cell ascorbic acid.

reported that LPL deficiencies are related to low levels of HDL-C [63]. Alternatively, it has been suggested that HDL production may be elevated by the cytochrome P-450 system, whose activity may be inducible by AA [64].

Oxidation of HDL has been shown to modify the structure of its major protein component, apolipoprotein A-I (apoA-I) [65]. In doing so, HDL has a depleted capacity to stimulate efflux of total cholesterol and cholesterol esters from foam cells $[66,67]$. Supplementation with antioxidant vitamins such as AA has been shown to be protective against HDL oxidation [68], although further studies are warranted. HDL-C may also be indirectly affected by AA, as a reduction in the expression and subsequent plasma concentration of apoA-I has been found in transgenic rats unable to synthesize AA [69].

It has been proposed that the reduction of TG levels by AA may also be attributable to an effect on LPL [70]. In rats and rabbits fed cholesterol, Sokoloff 
et al. [70] found a gradual decline in LPL activity, accompanied by an increase in TG levels. However, additional AA inhibited the reduction in LPL activity and the associated elevation of TG levels. In contrast, Nambisan and Kurup [16] found the LPL activity in the aorta to be independent of the AA concentration.

\section{EFFECT OF AA ON LIPID PEROXIDATION}

Lipid peroxidation and oxidative modification of LDL have been proposed as important steps in the atherosclerotic process. Consequently, the antioxidant action of AA means that it may facilitate inhibition of atherosclerotic development. Although the methodology used to assess this process requires further research, in vitro studies support the idea that $\mathrm{AA}$ is effective in protecting lipids from peroxidative damage induced by a variety of sources [71-76].

Studies in animals have shown that high levels of AA added to the diet have reduced lipid peroxidation in iron-overloaded rats [77] and guinea pigs [78], and in rabbits when combined with vitamin E supplementation [67]. Similarly, AA therapy in AA-deficient guinea pigs [79] has resulted in decreased lipid peroxidation.

Supplementation with AA in smokers has led to inconsistent results. Some studies have shown a reduction in lipoprotein oxidation $[80,81]$, but others have not $[51,52,82-84]$. In human studies where AA has been administered with other antioxidants, decreased lipid peroxidation resulted [68, 85-88]. Supplementation of smokers with dietary sources of AA and $\beta$-carotene supported these findings [89]. Consequently, although in vitro and animal studies support the action of AA as an antioxidant, human studies which have examined the effect of dietary/ supplemental AA on lipid peroxidation are inconclusive.

AA may also demonstrate its antioxidant functions via its putative role in the regeneration of vitamin $\mathrm{E}$ ( $\alpha$-tocopherol) from the $\alpha$-tocopheroxyl radical [8]. In studies where high doses of AA have been administered to animals, some investigators have shown elevated vitamin E concentrations in plasma [90] and in tissues $[91]$, but others have not $[92,93]$. There is also a lack of controlled human studies to support the in vitro observations. Previous studies in smokers and healthy women have not demonstrated an effect of AA supplementation on plasma tocopherol levels $[51,80,81,83,94,95]$. This is despite variations in AA doses ( 300 to $1,500 \mathrm{mg} /$ day) and duration of supplementation (14 days to 2 months). In contrast, Benzie and Strain [96] found that supplementation in 10 apparently healthy men and women with $1,000 \mathrm{mg} \mathrm{AA} /$ day for 4 weeks resulted in significant increases in total vitamin $\mathrm{E}$ concentrations and a highly significant increase in median lipid standardized vitamin E concentration. Similarly, a study in a healthy elderly population showed that AA supplement use was significantly correlated with plasma $\alpha$-tocopherol levels in females [97]. While to date, AA has not been consistently shown to enhance $\alpha$-tocopherol levels in vivo, other mechanisms by which it can exert its antioxidant functions have been reported [98].

Vol. 26, No. 2, 1999 
Table 3. Summary of literature on AA and copper indices in humans.

\begin{tabular}{|c|c|c|c|}
\hline Subjects & Study design & AA dose & Results \\
\hline $11 \mathrm{M}$ & $\begin{array}{l}3 \text { weeks } \\
\text { (metabolic unit) }\end{array}$ & $\begin{array}{l}0.07-9 \mathrm{mg} / \mathrm{kg} \\
\mathrm{BW} / \mathrm{d} .605 \mathrm{mg} / \mathrm{d}\end{array}$ & $\begin{array}{l}\mathrm{Cu} \text { absorption, excretion and serum } \\
\text { levels were unaffected by AA dose. Cp } \\
\text { oxidase activity reduced by } 21 \% \text { with } \\
\text { the highest AA dose [99]. }\end{array}$ \\
\hline $10 \mathrm{~F}$ & $\begin{array}{l}4 \text { weeks } \\
\text { (crossover) }\end{array}$ & $\begin{array}{l}17 \mathrm{mg} / \mathrm{kg} \mathrm{BW} / \mathrm{d} \\
1,000 \mathrm{mg} / \mathrm{d}\end{array}$ & $\begin{array}{l}\text { Reduction in } \mathrm{E}-\mathrm{Cu} \text { by } 23 \% \text { and E- } \\
\text { SOD by } 14.7 \% \text { during AA sup- } \\
\text { plementation }[100] \text {. }\end{array}$ \\
\hline $13 \mathrm{M}$ & $\begin{array}{l}64 \text { days } \\
\text { (parallel) }\end{array}$ & $\begin{array}{l}21 \mathrm{mg} / \mathrm{kg} \mathrm{BW} / \mathrm{d} . \\
1,500 \mathrm{mg} / \mathrm{d}\end{array}$ & $\begin{array}{l}\text { Fall in serum } \mathrm{Cu} \text { and } \mathrm{Cp} \text { activity after } \\
28 \text { days of } \mathrm{AA} \text { dose. This effect was } \\
\text { reversed } 20 \text { days after AA was with- } \\
\text { drawn [101]. }\end{array}$ \\
\hline $8 \mathrm{~F}$ & $\begin{array}{l}42 \text { days } \\
\text { (metabolic ward) }\end{array}$ & $\begin{array}{l}1.5-25 \mathrm{mg} / \mathrm{kg} \\
\mathrm{BW} / \mathrm{d} .1,500 \mathrm{mg} / \mathrm{d}\end{array}$ & $\begin{array}{l}\mathrm{Cp} \text { activity was reduced due to a slight } \\
\text { increase in } \mathrm{Cp} \text { protein [102]. }\end{array}$ \\
\hline $32 \mathrm{M}, 21 \mathrm{~F}$ & $\begin{array}{l}8 \text { weeks } \\
\text { (parallel) }\end{array}$ & $\begin{array}{l}29-33 \mathrm{mg} / \mathrm{kg} \mathrm{BW} / \\
\text { d. } 2,000 \mathrm{mg} / \mathrm{d}\end{array}$ & Transient rise in $\mathrm{Cp}$ [103]. \\
\hline
\end{tabular}

$\mathrm{AA}=$ ascorbic acid; $\mathrm{BW}=$ body weight $\mathrm{Cp}=$ ceruloplasmin; $\mathrm{Cu}=$ copper; $\mathrm{E}-\mathrm{Cu}=$ erythrocyte copper; $\mathrm{E}-\mathrm{SOD}=$ erythrocyte superoxide dismutase; $\mathrm{F}=$ female; $\mathrm{M}=$ male.

\section{POTENTIAL ADVERSE EFFECTS OF AA}

AA administration should be viewed with caution, as AA can exert potentially adverse effects via its interaction with transition metals. Animal and human studies [99-103] suggest that AA reduces copper status (Table 3). A reduction in copper status may include a reduction in the activity of copper dependent enzymes such as superoxide dismutase, a free radical quenching enzyme [100, 104].

AA is also a powerful reductant and is known to catalyze the reduction of non-heme ferric iron to ferrous iron which in turn aids its absorption [105, 106]. Whilst this is beneficial to those who are at risk of iron deficiency, enhancing iron absorption is not a favorable event for those with or at risk of hemochromatosis. Approximately $10 \%$ of Caucasians are born as carriers of hemochromatosis while $0.3 \%$ are born with the disease which is the most common autosomal recessive disorder amongst Caucasians [107]. AA consumption in the presence of iron can cause mobilization of iron from the spleen which is then deposited into the liver. Excess iron can damage tissue by peroxidation of membrane lipids [108]. AA supplementation is also likely to precipitate earlier phenotypic expression of hemochromatosis [109].

\section{CONCLUSION}

Clinical trials conducted to examine the epidemiological relationship between AA and plasma lipids have produced equivocal results which suggests that AA may be a surrogate marker [110] for other dietary constituents such as flavonoids. 
The latter are being studied increasingly because of their potential roles in the prevention of the major chronic diseases [111-113].

\section{REFERENCES}

1. Enstrom, J.E., Kanim, L.E., and Klein, M.A. (1992): Vitamin C intake and mortality among a sample of the United States population. Epidemiology, 3, 194-202.

2. Knekt, P., Reunanen, A., Jarvinen, R., Seppanen, R., Heliovaara, M., and Aromaa, A. (1994): Antioxidant vitamin intake and coronary mortality in a longitudinal population study. Am. J. Epidemiol., 139, 1180-1189.

3. Gey, K.F., Brubacher, G.B., and Stahelin, H.B. (1987): Plasma levels of antioxidant vitamins in relation to ischemic heart disease and cancer. Am. J. Clin Nutr., 45, 1368-1377.

4. Gey, K.F., Moser, U.K., Jordan, P., Stahelin, H.B., Eichholzer, M., and Ludin, E. (1993): Increased risk of cardiovascular disease at suboptimal plasma concentrations of essential antioxidants: An epidemiological update with special attention to carotene and vitamin C. Am. J. Clin. Nutr., 57, 787S-797S.

5. Nyyssonen, K., Parviainen, M.T., Salonen, R., Tuomilehto, J., and Salonen, J.T. (1997): Vitamin $\mathrm{C}$ deficiency and risk of myocardial infarction: Prospective population study of men from eastern Finland. Br. Med. J., 314, 634-638.

6. Frei, B. (1991): Ascorbic acid protects lipids in human plasma and low-density lipoprotein against oxidative damage. Am. J. Clin. Nutr., 54, 1113S-1118S.

7. Steinberg, D., Parthasarathy, S., Carew, T.E., Khoo, J.C., and Witztum, J.L. (1989): Beyond cholesterol: Modifications of low-density lipoprotein that increases its atherogenicity. $N$. Engl. J. Med., 320, 915-924.

8. Tappel, A.L. (1968): Will antioxidant nutrients slow aging processes ? Geriatrics, 23, 97105.

9. Ginter, E. (1975): Ascorbic acid in cholesterol and bile acid metabolism. Ann. N.Y. Acad. Sci., 258, 410-421.

10. Guchait, R., Guha, B.C., and Ganguli, N.C. (1963): Metabolic studies on scorbutic guinea pigs. Biochem. J., 86, 193-197.

11. Ginter, E., Nemec, R., Cerven, J., and Mikus, L. (1973): Quantification of lowered cholesterol oxidation in guinea pigs with latent vitamin C deficiency. Lipids, 8, 135-141.

12. Horio, F., Ozaki, K., Oda, H., Makino, S., Hayashi, Y., and Yoshida, A. (1987): Effect of dietary ascorbic acid, cholesterol and PCB on cholesterol concentrations in serum and liver in a rat mutant unable to synthesise ascorbic acid. J. Nutr., 117, 1036-1044.

13. Uchida, K., Nomura, Y., Takase, H., Tasaki, T., Seo, S., Hayashi, Y., and Takeuchi, N. (1990): Effect of vitamin C depletion on serum cholesterol and lipoprotein levels in ODS $($ od $/$ od $)$ rats unable to synthesize ascorbic acid. J. Nutr., 120, 1140-1147.

14. Horio, F., Takahashi, N., Makino, S., Hayashi, Y., and Yoshida, A. (1991): Ascorbic acid deficiency elevates serum level of LDL-cholesterol in a rat mutant unable to synthesise ascorbic acid. J. Nutr. Sci. Vitaminol., 37, 63-71.

15. Nambisan, B., and Kurup, P.A. (1974): The effect of massive doses of ascorbic acid and methionine on the levels of lipids and glycosaminoglycans in the aorta of weanling rats. Atherosclerosis, 19, 191-199.

16. Nambisan, B., and Kurup, P.A. (1975): Ascorbic acid and glycosaminoglycan and lipid metabolism in guinea pigs fed normal and atherogenic diets. Atherosclerosis, 22, 447-461.

17. Gordon, T., Castelli, W.P., Hjortland, M.C., Kannel, W.B., and Dawber, T.R. (1977): HDL as a protective factor against coronary heart disease. Am. J. Med., 62, 707-714.

18. Bates, C., Mandal, A., and Cole, T. (1977): HDL cholesterol and vitamin-C status. Lancet, 2, 611

19. Burr, M., Bates, C., Milbank, J., and Yarnell, J. (1982): The relationship between plasma ascorbate and lipid concentrations in fasting men. Hum. Nutr. Clin. Nutr., 36C, 135-139.

Vol. 26, No. 2, 1999 
20. Dallal, G., Choi, E., Jacques, P., Schaefer, E., and Jacob, R. (1989): Ascorbic acid, HDL cholesterol and apolipoprotein A-I in an elderly Chinese population in Boston. J. Am. Coll. Nutr., 8, 69-74.

21. Choi, E.S.K., Dallal, G.E., Jacques, P.F., Russell, R.M., and McGandy, R.B. (1990): Correlation of plasma ascorbic acid with cardiovascular risk factors (abstract). Am. J. Clin. Nutr., 51 (Suppl.), 511.

22. Itoh, R., Yamada, K., Oka, J., Echizen, H., Suyama, Y., and Murakami, K. (1990): Serum ascorbic acid and HDL cholesterol in a healthy elderly Japanese population. Int. J. Vitam. Nutr. Res., 60, 360-365.

23. Hallfrisch, J., Singh, V.N., Muller, D.C., Baldwin, H., Bannon, M.E., and Andres, R. (1994): High plasma vitamin $\mathrm{C}$ associated with high plasma HDL- and $\mathrm{HDL}_{2}$ cholesterol. Am. J. Clin. Nutr., 60, 100-105.

24. Jacques, P.F. (1992): Effect of vitamin C on high-density lipoprotein cholesterol and blood pressure. J. Am. Coll. Nutr., 11, 139-144.

25. Jacques, P.F., Sulsky, S.I., Perrone, G.A., and Schaefer, E.J. (1994): Ascorbic acid and plasma lipids. Epidemiology, 5, 19-26.

26. Ness, A.R., Khaw, K.T., Bingham, S., and Day, N.E. (1996): Vitamin C status and serum lipids. Eur. J. Clin. Nutr., 50, 724-729.

27. Salonen, J.T., Salonen, R., Seppanen, K., Kantola, M., Parviainen, M., Alfthan, G., Maenpaa, P.H., Taskinen, E., and Rauramaa, R. (1988): Relationship of serum selenium and antioxidants to plasma lipoproteins, platelet aggregability and prevalent ischaemic heart disease in Eastern Finnish men. Atherosclerosis, 70, 155-160.

28. Church, J.P., Judd, J.T., Young, C.W., Kelsay, J.L., and Kim, W.W. (1984): Relationships among dietary constituents and specific serum clinical components of subjects eating self-selected diets. Am. J. Clin. Nutr., 40, 1338-1344.

29. Bazzarre, T.L., Kleiner, S.M., and Ainsworth, B.E. (1992): Vitamin C intake and lipid profiles of competitive male and female bodybuilders. Int. J. Sports Nutr., 2, 260-271.

30. Simon, J.A., Schreiber, G.B., Crawford, P.B., Frederick, M.M., and Sabry, Z.I. (1993): Dietary vitamin $C$ and serum lipids in black and white girls. Epidemiology, 4, 537-542.

31. Cerna, O., and Ginter, E. (1978): Blood lipids and vitamin-C status. Lancet, 1, 1055-1056.

32. Greco, A.M., and La Rocca, L. (1982): Correlation between chronic hypovitaminosis C in old age and plasma levels of cholesterol and triglycerides. Int. J. Vitam. Nutr. Res., 23, 129136.

33. Gatenby Davies, J.D., and Newson, J. (1974): Ascorbic acid and cholesterol levels in pastoral peoples in Kenya. Am. J. Clin. Nutr., 27, 1039-1042.

34. Elwood, P., Hughes, R., and Hurley, R. (1970): Ascorbic acid and serum cholesterol. Lancet, 2, 1197.

35. Ginter, E. (1976): Vitamin C and plasma lipids. N. Engl. J. Med., 294, 559-560.

36. Fidanza, A., Audisio, M., and Mastroiacovo, P. (1982): Vitamin C and cholesterol. Int. J. Vitam. Nutr. Res., 23, 153-171.

37. Dobson, H.M., Muir, M.M., and Hume, R. (1984): The effect of ascorbic acid on the seasonal variations in serum cholesterol levels. Scott. Med. J., 29, 176-182.

38. Gatto, L., Hallen, G., Brown, A., and Samman, S. (1996): Ascorbic acid supplementation produces a favourable lipoprotein profile in young women. J. Am. Coll. Nutr., 15, 154-158.

39. Samuel, P., and Shalchi, O.B. (1964): Effect of vitamin C on serum cholesterol in patients with hypercholesterolemia and arteriosclerosis. Circulation, 29, 24-25.

40. Crawford, G.P.M., Warlow, C.P., Bennett, B., Dawson, A.A., Douglas, A.S., Kerridge, D.F., and Ogston, D. (1975): The effect of vitamin C supplements on serum cholesterol, coagulation, fibrinolysis and platelet adhesiveness. Atherosclerosis, 21, 451-454.

41. Menne, I.V., Grey, P.C., Kotze, J.P., Sommers, D.K., Brown, J.M.M., and Spies, J.H. (1975): Ascorbic acid and blood lipid and uric acid levels of students. S. Afr. Med. J., 49, 22252228.

42. Peterson, V.E., Crapo, P.A., Weininger, J., Ginsberg, H., and Olefsky, J. (1995): Quanti- 
fication of plasma cholesterol and triglyceride levels in hypercholesterolemic subjects receiving ascorbic acid supplements. Am. J. Clin. Nutr., 28, 584-587.

43. Bordia, A.K. (1980): The effect of vitamin C on blood lipids, fibrinolytic activity and platelet adhesiveness in patients with coronary artery disease. Atherosclerosis, 35, 181-187.

44. Johnson, G.E., and Obenshain, S.S. (1981): Nonresponsiveness of serum high-density lipoprotein-cholesterol to high dose ascorbic acid administration in normal men. Am. J. Clin. Nutr., 34, 2088-2091.

45. Khan, A.R., and Seedarnee, F.A. (1981): Effect of ascorbic acid on plasma lipids and lipoproteins in healthy young women. Atherosclerosis, 39, 89-95.

46. Buzzard, I.M., McRoberts, M.R., Driscoll, D.L., and Bowering, J. (1982): Effect of dietary eggs and ascorbic acid on plasma lipid and lipoprotein cholesterol levels in healthy young men. Am. J. Clin. Nutr., 36, 94-105.

47. Wahlberg, G., and Walldius, G. (1982): Lack of effect of ascorbic acid on serum lipoprotein concentrations in patients with hypertriglyceridaemia. Atherosclerosis, 43, 283-288.

48. Burr, M.L., Bates, C.J., Goldberg, G., and Butland, B.K. (1985): Vitamin C and cholesterol in the elderly. Hum. Nutr. Clin. Nutr., 39C, 387-388.

49. Aro, A., Kyllastinen, M., Kostiainen, E., Gref, C.-G., Elfving, S., and Uusitalo, U. (1988): No effect on serum lipids by moderate and high doses of vitamin C in elderly subjects with low plasma ascorbic acid levels. Ann. Nutr. Metab., 32, 133-137.

50. Jacques, P.F., Sulsky, S.I., Perrone, G.A., Jenner, J., and Schaefer, E.J. (1995): Effect of vitamin $\mathrm{C}$ supplementation on lipoprotein cholesterol, apolipoprotein, and triglyceride concentrations. Ann. Epidemiol., 5, 52-59.

51. Nyyssonen, K., Poulsen, H.E., Hayn, M., Agerbo, P., Porkkala-Sarataho, E., Kaikkonen, J., Salonen, R., and Salonen, J.T. (1997): Effect of supplementation of smoking men with plain or slow release ascorbic acid on lipoprotein oxidation. Eur. J. Clin. Nutr., 51, 154-163.

52. Samman, S., Brown, A.J., Beltran, C., and Singh, S. (1997): The effect of ascorbic acid on plasma lipids and oxidisability of LDL in male smokers. Eur. J. Clin. Nutr., 51, 472-477.

53. Spittle, C.R. (1971): Atherosclerosis and vitamin C. Lancet, 2, 1280-1281.

54. Ginter, E., Cerven, J., Nemec, R., and Mikus, L. (1971): Lowered cholesterol catabolism in guinea pigs with chronic ascorbic acid deficiency. Am. J. Clin. Nutr., 24, 1238-1245.

55. Ginter, E. (1973): Cholesterol: Vitamin C controls its transformation to bile acids. Science, 179, 702-704.

56. Hornig, D., and Weiser, H. (1976): Ascorbic acid and cholesterol: Effect of graded oral intakes on cholesterol conversion to bile acids in guinea-pigs. Experientia, 32, 687-689.

57. Harris, W.S., Kottke, B.A., and Ravi Subbiah, M.T. (1979): Bile acid metabolism in ascorbic acid-deficient guinea pigs. Am. J. Clin. Nutr., 32, 1837-1841.

58. Bjorkhem, I., and Kallner, A. (1976): Hepatic $7 \alpha$-hydroxylation of cholesterol in ascorbatedeficient and ascorbate-supplemented guinea pigs. J. Lipid Res., 17, 360-365.

59. Holloway, D.E., and Rivers, J.M. (1981): Influence of chronic ascorbic acid deficiency and excessive ascorbic acid intake on bile acid metabolism and bile composition in the guinea pig. J. Nutr., 111, 412-424.

60. Holloway, D.E., Peterson, F.J., Prigge, W.F., and Gebhard, R.L. (1981): Influence of dietary ascorbic acid upon enzymes of sterol biosynthesis in guinea pigs. Biochem. Biophys. Res. Commun., 102, 1283-1289.

61. Aulinskas, T.H., Van der Westhuyzen, D.R., and Coetzee, G.A. (1983): Ascorbate increases the number of low density lipoprotein receptors in cultured arterial smooth muscle cells. Atherosclerosis, 47, 159-171.

62. Goldberg, I.J., Blaner, W.S., Vanni, T.M., Moukides, M., and Ramakrishnan, R. (1990): Role of lipoprotein lipase in the regulation of high density lipoprotein apolipoprotein metabolism. J. Clin. Invest., 86, 463-473.

63. Eckel, R.H. (1989): Lipoprotein lipase: A multifunctional enzyme relevant to common metabolic diseases. N. Engl. J. Med., 320, 1060-1068.

64. Ginter, E. (1989): Ascorbic acid in cholesterol metabolism and in detoxification of xenobio-

Vol. 26, No. 2, 1999 
tic substances: Problem of optimum vitamin C intake. Nutrition, 5, 369-374.

65. Anantharamaiah, G.M., Hughes, T.A., Iqbal, M., Gawish, A., Neame, P.J., Medley, M.F., and Segrest, J.P. (1988): Effect of oxidation on the properties of apolipoproteins A-I and A-II. J. Lipid Res., 29, 309-318.

66. Nagano, Y., Arai, H., and Kita, T. (1991): High density lipoprotein loses its effect to stimulate efflux of cholesterol from foam cells after oxidative modification. Proc. Natl. Acad. Sci. U.S.A., 88, 6457-6461.

67. Morel, D.W., De La Llera-Moya, M., and Friday, K.E. (1994): Treatment of cholesterol-fed rabbits with dietary vitamins $\mathrm{E}$ and $\mathrm{C}$ inhibits lipoprotein oxidation but not development of atherosclerosis. J. Nutr., 124, 2123-2130.

68. Rifici, V.A., and Khachadurian, A.K. (1996): Effects of dietary vitamin C and E supplementation on the copper mediated oxidation of HDL and on HDL mediated cholesterol efflux. Atherosclerosis, 127, 19-26.

69. Horio, F., Ikeda, S., and Yoshida, A. (1993): L-Ascorbic acid regulates the expression of apolipoprotein A-I gene in scurvy-prone ODS rats. XV Int. Congr. Nutr. Adelaide, Int. Union Nutr. Sci., 2, 781.

70. Sokoloff, B., Hori, M., Saelhof, C., McConnell, B., and Imai, T. (1967): Effect of ascorbic acid on certain blood fat metabolism factors in animals and man. J. Nutr., 91, 107-118.

71. Frei, B., Stocker, R., and Ames, B.N. (1988): Antioxidant defenses and lipid peroxidation in human blood plasma. Proc. Natl. Acad. Sci. U.S.A., 85, 9748-9752.

72. Niki, E. (1991): Action of ascorbic acid as a scavenger of active and stable oxygen redicals. Am. J. Clin. Nutr., 54, 1119S-1124S.

73. Frei, B. (1991): Ascorbic acid protects lipids in human plasma and low-density lipoprotein against oxidative damage. Am. J. Clin. Nutr., 54, 1113S-1118S.

74. Jialal, I., Vega, G.L., and Grundy, S.M. (1990): Physiologic levels of ascorbate inhibit the oxidative modification of low density lipoprotein. Atherosclerosis, 82, 185-191.

75. Suzukawa, M., Abbey, M., Clifton, P., and Nestel, P.J. (1996): Enhanced capacity of n-3 fatty acid-enriched macrophages to oxidize low density lipoprotein mechanisms and effects of antioxidant vitamins. Atherosclerosis, 124, 157-169.

76. Mukhopadhyay, M., Mukhopadhyay, C.K., and Chatterjee, I.B. (1993): Protective effect of ascorbic acid against lipid peroxidation and oxidative damage in cardiac microsomes. $\mathrm{Mol}$. Cell. Biochem., 126, 69-75.

77. Dillard, C.J., Downey, J.E., and Tappel, A.L. (1984): Effect of antioxidants on lipid peroxidation in iron-loaded rats. Lipids, 19, 127-133.

78. Cadenas, S., Rojas, C., Perez-Campo, R., Lopez-Torres, M., and Barja, G. (1994): Effect of dietary vitamin $\mathrm{C}$ and catalase inhibition on antioxidants and molecular markers of oxidative damage in guinea pigs. Free Radical Res., 21, 109-118.

79. Kunert, K.-J., and Tappel, A.L. (1983): The effect of vitamin C on in vivo lipid peroxidation in guinea pigs as measured by pentane and ethane production. Lipids, 18, 271-274.

80. Harats, D., Ben-Naim, M., Dabach, Y., Hollander, G., Havivi, E., Stein, O., and Stein, Y. (1990): Effect of vitamin C and E supplementation on susceptibility of plasma lipoproteins to peroxidation induced by acute smoking. Atherosclerosis, 85, 47-54.

81. Fuller, C., Grundy, S., Norkus, E., and Jialal, I. (1995): Effect of ascorbate supplementation on low density lipoprotein oxidation in smokers. Atherosclerosis, 119, 139-150.

82. Belcher, J.D., Balla, J., Balla, G., Jacobs, D.R., Jr., Gross, M., Jacob, H.S., and Vercellotti, G.M. (1993): Vitamin E, LDL, and endothelium. Brief oral vitamin supplementation prevents oxidized LDL-mediated vascular injury in vitro. Arterioscler. Thromb., 13, 1779. 1789.

83. Mulholland, C.W., Strain, J.J., and Trinick, T.R. (1996): Serum antioxidant potential, and lipoprotein oxidation in female smokers following vitamin C supplementation. Int. J. Food Sci. Nutr., 47, 227-231.

84. Brown, A.J. (1998): Paradoxical effects of acute cigarette smoking on plasma antioxidant status in humans. Nutr. Res., 18, 1499-1519. 
85. Rifici, V.A., and Khachadurian, A.K. (1993): Dietary supplementation with vitamins C and $\mathrm{E}$ inhibits in vitro oxidation of lipoproteins. J. Am. Coll. Nutr., 12, 631-637.

86. Do, B.-K.Q., Garewal, H.S., Clements, N.C., Peng, Y.-M., and Habib, M.P. (1996): Exhaled ethane and antioxidant vitamin supplements in active smokers. Chest, 110, 159-164.

87. Reilly, M., Delanty, N., Lawson, J.A., and FitzGerald, G.A. (1996): Modulation of oxidant stress in vivo in chronic cigarette smokers. Circulation, 94, 19-25.

88. Mosca, L., Rubenfire, M., Mandel, C., Rock, C., Tarshis, T., Tsai, A., and Pearson, T. (1997): Antioxidant nutrient supplementation reduces the susceptibility of low density lipoprotein to oxidation in patients with coronary artery disease. J. Am. Coll. Cardiol, , 30, 392-399.

89. Abbey, M., Noakes, M., and Nestel, P.J. (1995): Dietary supplementation with orange and carrot juice in cigarette smokers lowers oxidation products in copper oxidized low-density lipoproteins. J. Am. Diet. Assoc., 95, 671-675.

90. Chen, L.H., and Chang, M.L. (1978): Effect of dietary vitamin E and vitamin C on respiration and swelling of guinea pig mitochondria. J. Nutr., 108, 1616-1621.

91. Bendich, A., D'Apolito, P., Gabriel, E., and Machlin, L.J. (1984): Interaction of dietary vitamin $\mathrm{C}$ and vitamin $\mathrm{E}$ on guinea pig immune responses to mitogens. J. Nutr., 114, 15881593.

92. Chen, L.H. (1981): An increase in vitamin $\mathrm{E}$ requirement induced by high supplementation of vitamin C in rats. Am. J. Clin. Nutr., 34, 1036-1041.

93. Burton, G., Wronska, U., Stone, L., Foster, D., and Ingold, K. (1990): Biokinetics of dietary RRR- $\alpha$-tocopherol in the male guinea pig at three dietary levels of vitamin C and two levels of vitamin E. Evidence that vitamin C does not "spare" vitamin E in vivo. Lipids, 25, 199-210.

94. Keith, R.E., Chrisley, B.M., and Driskell, J.A. (1980): Dietary vitamin C supplementation and plasma vitamin E levels in humans. Am. J. Clin. Nutr., 33, 2394-2395.

95. Jacob, R.A., Kutnink, M.A., Csallany, A.S., Daroszewska, M., and Burton, G.W. (1996): Vitamin C nutriture has little short-term effect on vitamin E concentrations in healthy women. J. Nutr., 126, 2268-2277.

96. Benzie, I.F.F., and Strain, J.J. (1997): Vitamin C supplementation associated with improved vitamin E status (Abstract). Proceedings of 16th International Congress of Nutrition, p. 44: PW 3.3.

97. Jacob, R.A., Otradovec, C.L., Russell, R.M., Munro, H.N., Hartz, S.C., McGandy, R.B., Morrow, F.D., and Sadowski, J.A. (1988): Vitamin C status and nutrient interactions in a healthy elderly population. Am. J. Clin. Nutr., 48, 1436-1442.

98. Halliwell, B. (1996): Vitamin C: Antioxidant or pro-oxidant ? Free Radical Res., 25, 439454.

99. Jacob, R., Skala, J., O’Maye, S., and Turnlund, J. (1987): Effect of varying ascorbic acid intakes on copper absorption and caeruloplasmin levels in men. J. Nutr., 117, 2109-2115.

100. Hallen, G., Ahmad, Z.I., and Samman, S. (1994): The impact of micronutrient interactions on antioxidant status in healthy subjects: Ascorbic acid and copper. Proc. Nutr. Soc. Aust., $18,86$.

101. Finley, E.B., and Cerlewski, F.L. (1983): Influence of ascorbic acid on copper status in young adult men. Am. J. Clin. Nutr., 37, 553-556.

102. Milne, D., Klevay, L., and Hunt, J.R. (1988): Effects of ascorbic acid supplements and a diet marginal in copper on indices of copper nutriture in women. Nutr. Res., 8, 865-873.

103. Pekiner, B., and Nebioglu, S. (1994): Effect of vitamin C on copper and iron status in men and guinea pigs. J. Nutr. Sci. Vitaminol., 40, 401-410.

104. Samman, S. (1993): Dietary versus cellular zinc: The antioxidant paradox. Free Radical Biol. Med., 14, 95-96.

105. Samman, S. (1997): Chapter 10: Zinc and copper, in Essentials of Human Nutrition, ed. by Mann, J.I., and Truswell, A.S., Oxford University Press, Oxford, pp. 151-159.

106. Hallberg, L., Brune, M., and Rossander, L. (1986): Effect of ascorbic acid on iron absorp-

Vol. 26, No. 2, 1999 
tion from different types of meals. Hum. Nutr. Appl. Nutr., 40A, 97-113.

107. Simopoulos, A.P., Herbert, V., and Jacobson, B. (1993): Genetic Nutrition: Design a Diet Based on Your Family Medical History, Macmillan, New York, pp. 158-162.

108. Nienhuis, A.W. (1981): Vitamin C and iron. N. Engl. J. Med., 304, 170-171.

109. George, D.K., and Powell, L.W. (1997): Review article: The screening, diagnosis and optimal management of haemochromatosis. Aliment. Pharmacol. Ther., 11, 631-639.

110. Samman, S. (1997): Nutrition editorial: Vitamin C and coronary heart disease. Curr. Opin. Lipidol., 8, U47-48.

111. Cook, N.C., and Samman, S. (1996): Flavonoids: Chemistry, metabolism, cardioprotective effects and dietary sources. J. Nutr. Biochem., 7, 66-76.

112. Samman, S., Lyons-Wall, P.M., Cook, N.C., and Naghii, M.R. (1996): Minor dietary factors in relation to coronary heart disease-flavonoids, isoflavones and boron. J. Clin. Biochem. Nutr., 20, 173-180.

113. Lyons Wall, P., and Samman, S. (1997): Flavonoids-dietary perspectives and health benefits. Proc. Nutr. Soc. Aust., 21, 106-114. 